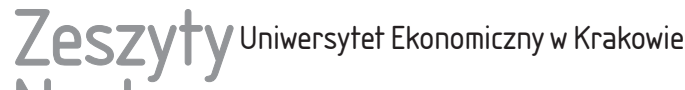 Naukowe
}

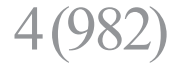

ISSN 1898-6447

e-ISSN 2545-3238

Zesz. Nauk. UEK, 2019; 4(982): 95-109

https://doi.org/10.15678/ZNUEK.2019.0982.0406

Fabio Fragomeni

Rosalba Rizzo

\section{The Economic Impact of Climate Change in Italy}

\begin{abstract}
Objective: In addition to being a threat to human health and life, climate change is an economic threat. The objectives of this article are to reflect on the consequences of global warming on Italian economic dynamics and to report on the costs and benefits of adapting strategies in a specific area at risk in Italy, particularly coastal erosion/flooding.

Research Design \& Methods: The article places particular emphasis on the analysis of the situation in this area to be used for proper economic evaluation.

Findings: While the climate change does not end at level of the economy, reflecting on prospective economic losses can help to understand climate risks. The research is limited by a lack of analysis involving other coastal areas at risk in Italy.

Implications / Recommendations: The strategies adapted in these areas at risk pose new interesting questions about the climate risks.

Contribution: The study examines global warming and highlights the strategy of adaptation as a process for reducing our vulnerability to the harmful effects of climate change.
\end{abstract}

Keywords: climate change, climate risks, economic impact, adaptation strategies. JEL Classification: Q54.

Fabio Fragomeni, University of Messina, Piazza Pugliatti 1, 98122 Messina, Italy, e-mail: ffragomeni @ unime.it, ORCID: https://orcid.org/0000-0002-1455-0033.

Rosalba Rizzo, University of Messina, Piazza Pugliatti 1, 98122 Messina, Italy, e-mail: rrizzo @unime.it, ORCID: https://orcid.org/0000-0001-5676-2758.

This is an open access article distributed under the terms of the Creative Commons Attribution-NonCommercial-NoDerivatives 4.0 License (CC BY-NC-ND 4.0); https://creativecommons.org/ licenses/by-nc-nd/4.0/ 


\section{Introduction}

Ongoing climate change is rapidly leading to major global upheavals (Gilbert \& Vincent 2013, Cline 1992). If we want to avoid catastrophic consequences for ourselves and the planet, we must act at once and in a targeted manner. So warned an environmental report published by the IPCC (Intergovernmental Panel on Climate Change), on October 8th, 2018 in South Korea. Limiting global warming to $1.5^{\circ} \mathrm{C}$ will require rapid and unprecedented changes in all aspects of human activity.

Drawing together 6,000 scientific references and 91 authors and reviewers from 40 different countries, the IPCC report maintains that since the beginning of the industrial era, human activities have caused global temperature to rise by $1^{\circ} \mathrm{C}$, and at an unprecedented speed. We are already seeing the consequences, including extreme weather events, rising sea levels and melting glaciers in the Arctic. The study also highlights the significant problems which could be avoided by limiting global warming from $2^{\circ} \mathrm{C}$ to $1.5^{\circ} \mathrm{C}$.

Among these problems can be counted rising global sea levels, which could, by 2100 , be $10 \mathrm{~cm}$ higher, drastically changing the lives of populations living in coastal areas. The likelihood of the Arctic Ocean remaining void of sea ice in the summer would be much higher. Coral reefs would already have decreased by $70-90 \%$ with warming of $1.5^{\circ} \mathrm{C}$, while at $2^{\circ} \mathrm{C}$ all would be lost $(>99 \%)$. The oceans would face even more intense acidification, with far more dire consequences for marine flora and fauna. Summers would be even more torrid and extreme climatic events would make the cultivation of cereals, the first source of food for billions of people in the world, more difficult and expensive.

Walter Ricciardi, president of the Istituto Superiore della Sanità, has expressed his point of view clearly on this issue: "Climate change is the real global threat of this century and crosses the entire human and environmental condition. The quality of our life, our health and our very survival are put at serious risk. Managing these transformations, changing course has become the real emergency and the real challenge". He adds: "We have only two generations, less than 20 years, to save the planet from climate change and the devastating effects that these will have on human and territorial health. In a few decades it may already be too late. Already today, thousands of deaths annually in Europe are linked to climate change, but they will be millions in the near future if we do not act immediately".

The World Health Organisation (WHO) speaks of 7 million deaths annually linked to climate change. In Italy, meanwhile, as many as $12 \%$ of pedatric hospital admissions are related to pollution. In Rome, from 3 to 5 December 2018, the first international symposium on Health and Climate Change was held, from which the first international map on climate and health will be designed, containing a series 
of recommendations to counter the risks linked to climate change. The event was attended by 500 researchers from 30 countries. It is essential that the scientific community share this awareness to make change a responsibility and a common commitment (Sergi et al. 2019). The next few years, in fact, will be the most important in our history.

\section{The Impact of Climate Change: Social, Economic and Natural Dimensions}

The discussion surrounding climate change is complex. Not only because the theme involves a plurality of interconnected problems that are difficult to disentangle, but above all because it has a markedly social and economic dimension (Deke et al. 2001, Sergi 2003, Adekola \& Sergi 2016). Everything that revolves around the theme of climate change - and therefore the impact of man on the environment - directly involves methods of both production and consumption and people's lifestyles. A set, that is, of processes, micro-behaviours and actions - from the manufacture of products to their disposal; from diet to the means of transport. At the aggregate level, these are not at all neutral in terms of environmental impact.

The interest in environmental issues has emerged after decades of the issue being treated as a marginal and, at times, naïve topic (Nordhaus 1994, 1991a, 1991b). The inertia of global warming and its effects was demonstrated, for example, by a report from the Club of Rome, an MIT think tank that sought to estimate the impact of increased production, population and environmental pollution on long-term economic growth. Published in 1972, the work, entitled The Limits to Growth (www.clubofrome.org/report/the-limits-to-growth/, accessed: 29 October 2019), highlighted for the first time the extremely negative impact of emissions and climate change on long-term economic growth. It also anticipated what is happening today.

Humans' impact on the environment, however, has more distant roots in time. During the first and second industrial revolution, $\mathrm{CO}_{2}$ emissions grew radically, prompting global temperatures to rise. If you look at the following three graphs (Figures 1-3) in the 1870-2016 period, the growth of per capita income, emissions and temperatures follow the same trend.

From these graphs, the social and economic dimension of climate change clearly emerges: increased emissions are the other side of the coin of improved well-being. Since 1800, societies (particularly western ones) have seen their growth per capita grow considerably. This has coincided with an exponential increase in emissions. That, in turn, can be attributed to an increase in life expectancy and an incredible 
GDP per capita adjusted for price changes over time (inflation) and price differences between countries - it is measured in international-\$ in 2011 prices

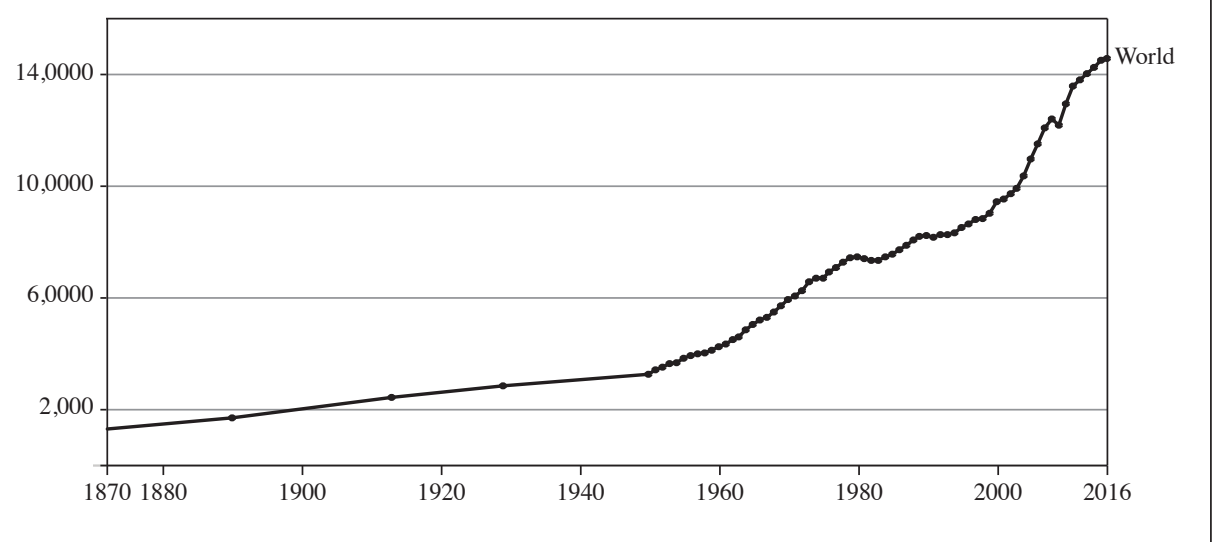

Fig. 1. GDP per capita

Note: These series are adjusted for price differences between countries using multiple benchmark years, and are therefore suitable for cross-country comparisons of income levels at different points in time.

Source: Maddison Project Database (2018), retrieved from: M. Roser (2019), Economic Growth, published online at OurWorldInData.org, https://ourworldindata.org/economic-growth (accessed: 29 October 2019).

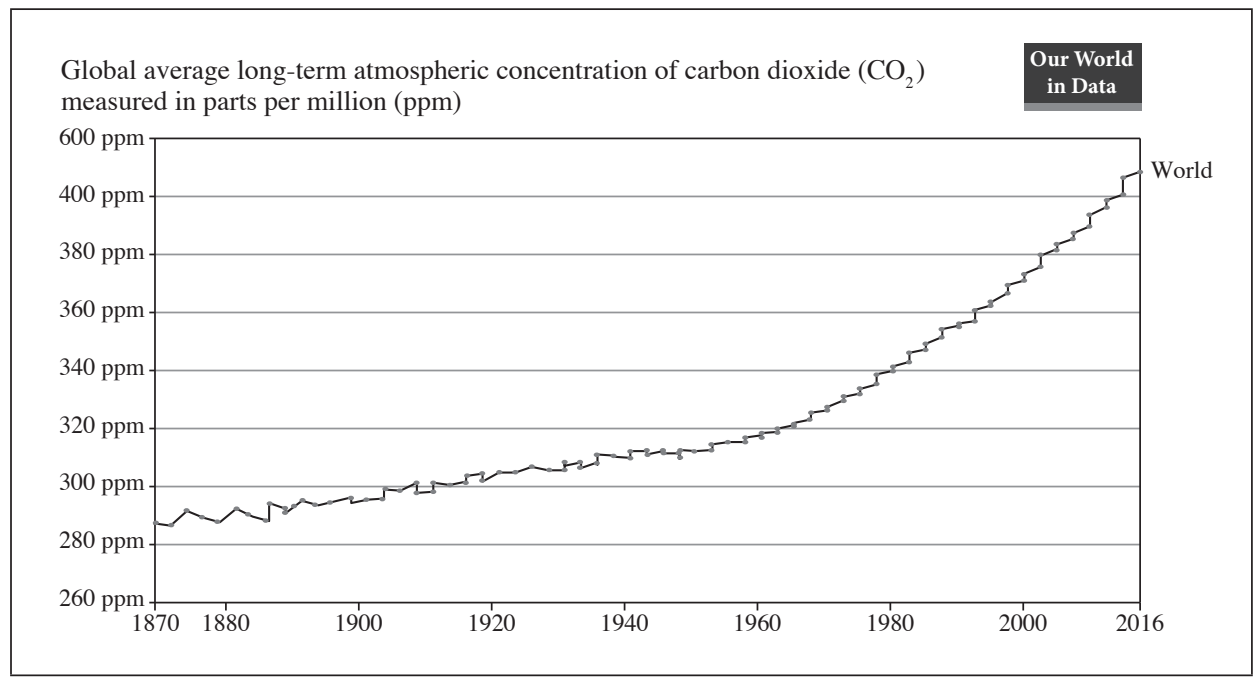

Fig. 2. Atmospheric $\mathrm{CO}_{2}$ Concentration

Source: Scripps CO2 Program, retrieved from: H. Ritchie, M. Roser (2019), $\mathrm{CO}_{2}$ and Greenhouse Gas Emissions, published online at OurWorldInData.org, https://ourworldindata.org/co2-andother-greenhouse-gas-emissions (accessed: 29 October 2019). 
expansion of consumption levels. The close connection between economic growth (and therefore the growth of well-being) and increased environmental impact has led to the latent difficulty in rethinking certain models of production and consumption. That is, to eradicate the belief that one cannot act on the second aspect - emissions - without negatively affecting the first - economic growth.

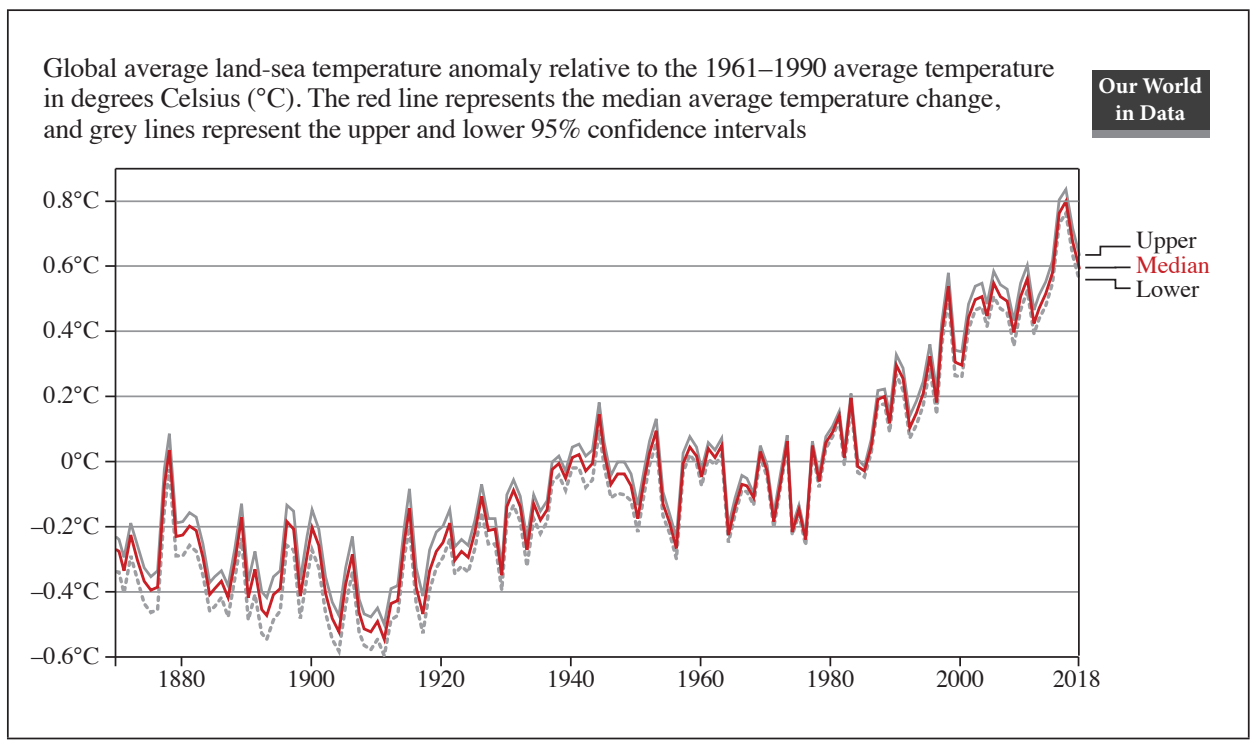

Fig. 3. Average Temperature Anomaly, Global

Source: Hadley Centre (HadCRUT4), retrieved from: H. Ritchie, M. Roser (2019), $\mathrm{CO}_{2}$ and Greenhouse Gas Emissions, published online at OurWorldInData.org, https://ourworldindata.org/co2and-other-greenhouse-gas-emissions (accessed: 29 October 2019).

Nor should we be deceived into believing that developing economies are the main culprits of pollution: if national economies - China's in particular - are seen from a diachronic perspective (from 1870 to 2014) compared to that of the Western countries, the United States, to take one example, has a much greater responsibility in terms of the cumulative emissions it has created, per capita levels notwithstanding. China's emissions, which are the result of that country having become the "world's manufacturer", are not only connected to improving the living conditions of the Chinese, but also to the lifestyle of Western countries, which import the products China produces.

Given the certain role of human society on climate change, and the net of possible disputes over responsibilities and who should be "the first mover" with respect to an incisive economic-productive conversion, the real challenge seems to be seeing such reconversion, and more generally a transition towards sustain- 
able models, as an opportunity for development, and no longer as an inevitable "burden". That is, being able to understand the problem as an opportunity. Acknowledging the possibilities offered by the circular economy and new business models (e.g., Goyal, Sergi \& Kapoor 2014, Goyal \& Sergi 2015, Goyal et al. 2017) would be a step in the right direction. If the economic-productive system is in fact based on a so-called take-make-dispose linear model, which involves - on the production and consumption side - a life cycle of one-way consumer goods (from factory to landfill), at the base of the circular economy is the idea of recovering and reusing the waste that is produced during the production cycle and at the end of the product life cycle. In other words, if the classical model involves an inefficient use of resources, since it produces waste that corresponds to economic waste and negative externalities for society, the circular model runs in the opposite direction. This has significant effects in terms of reducing the environmental impact, since everything related to a reduction in waste and reuse of materials implies lower emissions connected to their disposal and new production.

\section{The Socio-economic Dimension of Adaptation Measures in Italy}

There are two main approaches to reducing the risks attending climate change (McCarthy et al. 2001). On the one hand there are mitigation actions, which aim to eliminate or progressively reduce gas emissions that increase the natural greenhouse effect. The other approach uses adaptation strategies, or actions intended to minimise the negative consequences and the damage caused by possible climate change, both to the natural and socio-economic systems (Fioravanti, Piervitali \& Desito 2016, Brunetti, Maugeri \& Nanni 2006, Handbook... 1998).

The complex functioning of the climate system and the nature of atmospheric pollution due to anthropogenic climate change mean that the risk and damage due to climate change cannot be eliminated. Strategies for adapting to climate change are therefore necessary complements to mitigation strategies aimed at reducing greenhouse gas emissions. The IPCC report (2007) urgently needs to take adaptation measures as soon as possible to react to affects that are now inevitable and measures to mitigate climate change to alleviate and avoid greater consequences and future risks.

The need to adapt to the consequences of climate change appears from a series of important international documents, each of which gives its own definition of this key concept. In this context, we refer to the European Directive banning disposable plastic from 2021. Despite the obvious implications in terms of environmental protection (the WWF estimates that 33,000 disposable plastic bottles 
are released into the Mediterranean Sea every minute (www.ansa.it/canale_ambiente/notizie/natura/2019/06/07/nel-mediterraneo-33mila-bottiglie-di-plastica-alminuto-_4d9a9154-009f-439a-acc9-c5f1d4284867.html, accessed: 29 October 2019), the economic implications are anything but positive. Italy leads Europe in the production of disposable plastic, and it is estimated that around 3,000 people work in the sector (www.askanews.it/economia/2019/04/17/fareambientecondirettiva-ue-su-plastica-a-rischio-3000-lavoratori-pn_20190417_00213, accessed: 29 October 2019). Without a reconversion plan, these people would by 2021 find themselves unemployed. Here the strictly social dimension of the theme opens up once again, and the difficulty for political decision-makers to implement effective and acceptable solutions becomes clear.

Adaptation therefore aims to reduce the vulnerability of the systems considered, which in turn will depend on the definition of the challenge to be faced. Delving into greater detail, the assessment of vulnerability will be addressed through a series of relevant criteria (McCarthy 2001).

Although there is no single definition of adaptation (Bosello et al. 2007), two main forms can be distinguished: "programmed" adaptation through public or private bodies; and "autonomous" adaptation of natural and socio-economic systems. The first consists of measures implemented explicitly to mitigate or cancel the negative impacts of climate change, while the second encompasses conditions of resilience of natural and socio-economic systems.

Adaptation can also be carried out at different scales: individual, regional, national and European. The key role of a regional adaptation strategy is to prevent different atomistic-level adaptation strategies from coming into conflict with each other or even becoming counterproductive. Adaptation at a national level seeks to increase the adaptive role of the system as a whole. It consists of a set of initiatives that require the intervention of a public authority as both the uncertainty related to climate change and the degree of coordination and enforcement required can be a deterrent to the private agent. Important measures have already been adopted by Europe. These include the adoption, in 2015, of the European package on the circular economy. An effective scheme to combat climate change could be even more coordinated centrally to avoid environmental dumping schemes. It could include the transfer of companies in countries with less costs related to environmental and social regulations, while guaranteeing support for the phases of reconversion and transition. A recent paper (europeanclimate.org/ wp-content/uploads/2018/06/FINAL-MATERIAL-ECONOMICS-CIRCULAR-ECONOY-SUMMARY.pd, accessed: 29 October 2019) estimates that the consistent use of the circular model could reduce the $\mathrm{CO}_{2}$ emissions of European countries by more than $50 \%$ by 2050 , thus facilitating the achievement of the $2^{\circ} \mathrm{C}$ temperature increase target set by $\mathrm{COP} 21$, which foresees a reduction of emissions 
from the current 32 billion to 24 billion tons of $\mathrm{CO}_{2}$ by 2030. Although it is proven that circular economy schemes can generate significant economic opportunities, as well as benefits in terms of social well-being, it is less clear if such models are as efficacious, particularly considering the initial costs that can be passed on to companies (and to consumers) and the problems for the industrial sectors that would be replaced by these new models. This speaks to the difficulty of accepting and implementing a new paradigm of economic growth.

The planned adaptation strategies have as a starting point a detailed analysis of the impact of climate change, both in the current period and in a climate change perspective. Therefore, the level and type of adaptation depend on the vulnerability of the system, or on its degree of susceptibility to the negative impacts of climate change. This vulnerability is a function of both the process of adapting the system to a new situation and the very conditions that allow the system to adapt (Ferrara \& Farruggia 2007).

\section{Methodological Framework}

Before presenting the problems related to the evaluation of impacts and policies in the context of climate change, we will briefly describe the decision-making process in general, and present a conceptual reference model that is well suited to the type of evaluation analysis to be discussed in the following pages.

Several common elements can be identified in decision-making: they concern the public or private sector, as well as choices of policy, strategy or project. First of all, the decision-maker, which can be an individual or an institution, faces a problem. At the same time, it has the ability to intervene on various elements that characterise the problem, in order to pursue a pre-established objective. For this purpose, the decision-maker must, as a first step, identify operational decision-making criteria, which will ease both the identification of the different intervention options and their possible evaluation.

There may be two aims for assessing the impact of climate change and the related adaptation strategies. First, the decision maker may need to quantify, as far as is possible, the extent of the impact of climate change, with the aim of proving its relative importance. Secondly, the decision-maker may want to establish the relative costs and benefits of different strategies for adapting to specific consequences of climate change.

Regardless of the context in which it is to be applied - desert areas (Sciortino 2001), coastal areas (Eisenreich 2005), areas at risk of hydrogeological instability (Alpert et al. 2002), areas at risk of deglaciation, and also of the scale of investigation (European, national, regional or local) - a methodological approach that 
allows for an economic quantification of the impacts of climate change follows some common fundamental lines. There are three fundamental phases for an economic evaluation strategy concerning both the impact of climate change and the effectiveness and efficiency of different adaptation strategies. It should:

- outline one or more benchmark scenarios for the reference variables (for example, the sector for which the impacts of climate change are to be determined). The benchmark scenario will be used to assess the relative risks or the different adaptation strategies;

- define one or more future climate change scenarios, with and without adaptation policies, and their economic implications for the reference variables;

- compare the results between the benchmark and the scenarios with climate change, to quantify the economic impact of climate change and/or adaptation strategies on the reference variables.

First, it is important to highlight how climate change is not the only force bearing on socio-economic systems, but is rather an additional element of pressure increasing the criticality or vulnerability of these systems.

There are two important steps in the evaluation of the different strategies for adapting to climate change: the first is to define the reference scenario (benchmark), which assesses, first, the risks and the cost of climate change, and, second, the effectiveness and efficiency of the different adaptation options. The second step is to establish one or more future scenarios that take into consideration the expected changes in the climate, and therefore their impact on the reference variables. As in the case of the reference scenario, and perhaps to an even greater extent, the construction of future scenarios "with climate change" necessarily makes it difficult to anticipate future changes - including both climatic variables as well as the different impacts in specific sectors. It is therefore useful to develop a series of scenarios and hypotheses regarding the future climate.

Climate policies are important and may be characterised as pursuing mitigation or adaptation. While the former act to reduce the causes of climate change, the latter are intended to reduce the damage caused by it (Menne \& Ebi 2006). To evaluate the best option, a non-intervention hypothesis must be compared with different alternative intervention options. Each of them will have to evaluate effectiveness (the ability to reach the set goal), efficiency (the ability to minimise conflict between different stakeholders) and feasibility (the possibility of realisation). The matter is therefore particularly complex as it requires both technical and economic assessments as well as assessments of social, cultural and ultimately political impact. Furthermore, the numerous interactions that exist between economic, social and environmental responses to the implemented policies and between the policies themselves require the use of a systemic, or integrated multidisciplinary approach to intervention. 


\section{Sea Level Rise in the Fondi Plane: A Case Study Analysis}

This case study looks at an example of adaptation in Italy (D'Oria, Ferraresi \& Tanda 2017). It assesses the economic efficiency of adaptation actions in response to sea level rise in the Fondi plane (Antonioli \& Leoni 2001). This issue is conceptually referable to the problem of minimising total costs of climate change, as presented above. In this case, the problem is simplified because mitigation costs are not accounted for, as Fankhauser has pointed out (Fankhauser, Smith \& Tal 1999, Fankhauser 1995). It can be assumed that, even if mitigation measures are undertaken in coming years, they will fail to change the foreseen impacts on sea level rise before 2100 (the chosen time horizon). If adaptation measures are implemented, the residual damage will equal zero. This accords with the assumption that protecting coasts with suitable defensive measures will fully prevent the land from losing its economic value.

Given these assumptions, adaptation is justified, according to a cost efficiency approach, if this condition is fulfilled:

$$
\text { adaptation costs < expected damages without adaptation. }
$$

The expected damages without adaptation correspond to the value of land at risk of being permanently flooded. It has been assumed that all the land which is foreseen to reach an altitude below 0 within the time horizon under consideration will be lost forever, if proper defensive measures are not set up. The ultimate purpose of the analysis is therefore to establish how costly these measures are compared to a non-intervention scenario.

Three hypotheses on adaptation behaviours have been analysed:

Hypothesis 1: no adaptation and consequent inland loss;

Hypothesis 2: protect the land by strengthening the present system for land reclamation (waterscooping machines);

Hypothesis 3: protect the land by reconstructing a pre-existing dune as a first barrier to sea level rise.

Considering more than one adaptation option is particularly important when there is a high degree of social conflict between stakeholders (Qerimi \& Sergi 2015), with respect to the consequences implied by the choice of one or another adaptation option. Considering more than one option produces a more equitable evaluation study, by avoiding limiting a priori the decision set to a sub-set of workable solutions, and therefore implying that this or that group of stakeholders will be favoured. Besides, when decision processes are particularly complex, due to many different attributes to be considered in evaluating alternatives, a broader methodology, like multiple criteria analysis, can be more suitable than cost benefit analysis to tackle the decision-making. 
Before analysing the data, geographical and economic features of the Fondi plane are given as a background. The plane has a total surface of approximately 6,000 ha, 1,150 of which are already at an altitude below zero. Its territory includes most of the Fondi Municipality, and also includes little areas that lie within the Municipalities of Monte San Biagio and Sperlonga. The total population is some 30,000 inhabitants, and the average GDP per capita in 2002 was around EUR 13,000 per year.

The area comprises a vast reclaimed tract of land used primarily for agriculture (60\% intensive greenhouse cultivation); a $14 \mathrm{~km}$-long coastal area, with strong potential for tourism; Fondi lake, a brackish water endowed with rare species, and also promising strong potential for outdoor tourism; and, finally, a mainly agriculture-based economy characterised predominantly by small family enterprises.

With respect of the property rights of the land, a big share of the total surface is state-owned, and entirely zoned for agricultural use but also characterised by a high number of illegal houses. Part of this area is authorised for a property and land use change, meaning it will become private or "legitimated" land suitable for building houses and tourism infrastructure. The analysis was developed to calculate the economic value of areas at risk of permanent flooding, and to then compare them with the costs of the two optional land protection measures. The starting point was the quantification of the total area at risk, diversified by land use, obtained by applying GIS techniques (Geographic Information System) to the sea level-rise scenario for the next century (Antonioli 2000, 2002; Caiaffa \& Leoni 2002). Time milestones for quantifying the progressive extension of the area at risk were set at years 2002, 2050 and 2100. The land uses considered are agricultural, forest and residential.

Next, the estimation of the area at risk was refined by considering the type of soil in a given location (peat or non-peat soil) and the type of cultivation (reclaimed or non-reclaimed land). This was done with the help of aerial photographs of the area under investigation. The property type (private land, State property, Municipal property) was determined from a map representing the civic uses of the land.

Once the area at risk was quantified, an economic value was assigned to the land, differentiating by land use, soil nature and property regime. Where it could be obtained or determined, the commercial value of the land was attributed: such a value was based on interviews with local individuals such as real estate and land sale agencies and verified by comparison with national statistics (Istituto Nazionale di Economia Agraria, www.inea.it).

The income flow was derived by normalising the total income of the Municipality of Fondi with respect to the estimated population living in the area at risk at the three considered time milestones. The income flow generated in the areas at 
risk was added to the total monetary value of the stock (i.e. the commercial value of the land).

Given the crucial importance of the discount rate for the assessment of future damages, two rates, $1 \%$ and $3 \%$, were used for the sensitivity analysis. The international scientific community generally considers these rates suitable for use in impact assessment studies. Because the degree of uncertainty implied was sometimes high and the researcher's choice could influence the conclusions, two scenarios with different underlying hypotheses were analysed:

1) low scenario:

- null value of illegal houses,

- low housing value in areas authorised for changes to be made to property,

- high $\%$ of peat land, low $\%$ of greenhouse land;

2) high scenario:

$-0<$ value of illegal houses < value of legal houses,

- higher housing value in areas authorised for changes to be made to property, - low $\%$ of peat land, high $\%$ of greenhouse land.

Hence, the present value of the area at risk was calculated for each of the above scenarios and discount rates. The main variables on which the total value depends include the commercial value of agricultural areas, differentiated by the soil nature and the property regime; the commercial value of houses, differentiated by degree of legality of the buildings; and the income produced. The result provides a measure of the damage compared to the sea level rise in the Fondi plane without adaptation. Land protection measures were analysed with a simplified expert-based valuation method. In both cases experts were asked to produce a rough estimate of costs implied by the two alternative defences. Economic valuation of adaptation measures can be done at rising degrees of complexity, depending on the purpose of the analysis and on the level of the decision-making process (policy level, planning level, project level).

\section{Conclusions}

The Fondi Plane case study focuses on adaptation, and identifies the most efficient alternative of adaptation to an expected sea-level rise in the coastal area of the Fondi plane. It provides a sound methodological framework for the socio-economic evaluation of local interventions of adaptation through the application of cost-benefit analysis. The economic value of the areas at risk of flooding in the Fondi Plane is calculated to represent the "no intervention" option and compared with the costs of two alternative measures of land protection - improvement of the existing inland water drainage system and reconstruction of a pre-existing dune 
along the coast. Case specific results suggest that improving the drainage system would be more efficient than the other options. Of course, the results apply to the Fondi plane and may be quite different in another socio-economic and geographical context. The analysis of this case strongly suggests that the economic analysis should be complemented primarily with a social and political analysis of the local context as well as a technical feasibility study. The study also highlights how the social costs of local interventions can be very high and that the social acceptability of the adaptation options must be taken into account and become crucial to the process of evaluation.

\section{Bibliography}

Adekola A., Sergi B. S. (2016), Global Business Management: A Cross-Cultural Perspective, Routledge, New York.

Alpert P., Ben-Gai T., Baharad A., Benjamini Y., Yekutieli D., Colacino M., Diodato L., Ramis C., Homar V., Romero R., Michaelides S., Manes A. (2002), The Paradoxial Increase of Mediterranean Daily Rainfall in Spite of Decreased Total Values, "Geophysical Review Letters", vol. 29, https://doi.org/10.1029/2001GL013554.

Antonioli F. (2002), Vulnerabilità delle coste italiane: Rischio di allagamento da parte del mare (in:) La Risposta al Cambiamento Climatico in Italia. Vulnerabilità Climatica, Valutazioni SocioEconomiche delle Strategie di Adattamento, Misure di Mitigazione Forestale, ENEA.

Antonioli F., Leoni G. (2001), Relazione tecnica per Min. Amb., Progetto 4.8 Risanamento del Territorio e delle acque, Linea $3 b$ Pianure costiere italiane a rischio di allagamento del mare, $\mathrm{Cd}$ con mappe di 33 Piane a rischio.

Antonioli F. (2000), Le fluttuazioni recenti del livello del mare, "Energia Ambiente e Innovazione", vol. 46(6).

Bosello F., Kuik O., Tol R. S. J., Watkiss P. (2007), Costs of Adaptation to Climate Change: A Review of Assessment Studies with a Focus on Methodologies Used, EEA report, 6th Specific Agreement No 3602/B2005.EEA under the Framework Contract No. EEA/AIR/04/004.

Brunetti M., Maugeri M., Nanni T. (2006), Trends in the Daily Intensity of Precipitation in Italy and Teleconnections, "Il Nuovo Cimento 29 C", vol. 1.

Caiaffa E., Leoni G. (2002), Il contributo del GIS alla modellazione delle dinamiche territoriali: il caso di studio della Piana di Fondi (in:) La Risposta al Cambiamento Climatico in Italia. Vulnerabilità Climatica, Valutazioni Socio-Economiche delle Strategie di Adattamento, Misure di Mitigazione Forestale, ENEA.

Cline W. R. (1992), The Economics of Global Warming, Institute of International Economics, Washington, DC.

Deke O., Hooss K. G., Kasten C., Klepper G., Springer K. (2001), Economic Impact of Climate Change: Simulations with a Regionalized Climate-Economy Model, Working Paper, no 1065, Kiel Institute of World Economics, Kiel (Germany).

D’Oria M., Ferraresi M., Tanda G. M. (2017), Historical Trends and High-resolution Future Climate Projections in Northern Tuscanu (Italy), "Journal of Hydrology" vol. 555, https://doi.org/10.1016/j.jhydrol.2017.10.054. 
Eisenreich J. S. (2005), Climate Change and the European Water Dimension. A Report to the European Water Directors 2005, EU Report, no 21553.

Fankhauser S. (1995), Valuing Climate Change. The Economics of the Greenhouse, Earthscan, London.

Fankhauser S., Smith J. B., Tol R. S. J. (1999), Weathering Climate Change: Some Simple Rules to Guide Adaptation Decisions, "Ecological Economics", vol. 30, https://doi. org/10.1016/s0921-8009(98)00117-7.

Ferrara V., Farruggia A. (2007), Clima: istruzioni per l'uso. I fenomeni, gli effetti, le strategie, Edizioni Ambiente, Isola del Liri (Fr).

Fioravanti G., Piervitali E., Desiato F. (2016), Recent Changes of Temperature Extremes over Italy: An Index-based Analysis, "Theoretical and Applied Climatology", vol. 123, https://doi.org/10.1007/s00704-014-1362-1.

Gilbert A., Vincent C. (2013), Atmospheric Temperature Changes over the 20th Century at Very High Elevations in the European Alps from Englacial Temperatures, "Geophysical Research Letters", vol. 40, https://doi.org/10.1007/s00704-014-1362-1.

Goyal S., Esposito M., Kapoor A., Jaiswal M. P., Sergi B. S. (2014), Linking Up: Inclusive Business Models for Access to Energy Solutions at the Base of Pyramid in India, "International Journal of Business and Globalisation", vol. 12(4), https://doi. org/10.1504/ijbg.2014.062843.

Goyal S., Kapoor A., Esposito M., Sergi B. S. (2017), Understanding Business Model Literature Review of Concept and Trends, "International Journal of Competitiveness", vol. 1(2), https://doi.org/10.1504/ijc.2017.084715.

Goyal S., Sergi B. S. (2015), Social Entrepreneurship and Sustainability - Understanding the Context and Key Characteristics, "Journal of Security and Sustainability Issues", vol. 4(3), https://doi.org/10.9770/jssi.2015.4.3(7).

Goyal S., Sergi B. S., Kapoor A. (2014), Understanding the Key Characteristics of An Embedded Business Model for the Base of the Pyramid Markets, "Economics and Sociology", vol. 7(4), https://doi.org/10.14254/2071-789x.2014/7-4/2.

Handbook on Methods of Climate Change Impact Assessment and Adaptation Strategies (1998), J. F. Feenstra, I. Burton, J. B. Smith, R. S. J. Tol (eds), Vrije Universiteit, United Nations Environment Programme and Institute for Environmental Studies, NairobiAmsterdam.

IPCC (2007), Climate Change 2007: Synthesis Report. Contribution of Working Groups I, II and III to the Fourth Assessment Report of the Intergovernmental Panel on Climate Change, Core Writing Team, R. K. Pachauri, A. Reisinger (eds), IPCC, Geneva.

IPCC (2018), Global warming of $1.5^{\circ} \mathrm{C}$. An IPCC Special Report on the impacts of global warming of $1.5^{\circ} \mathrm{C}$ above pre-industrial levels and related global greenhouse gas emission pathways, in the context of strengthening the global response to the threat of climate change, sustainable development, and efforts to eradicate poverty, V. Masson-Delmotte, P. Zhai, H. O. Pörtner, D. Roberts, J. Skea, P. R. Shukla, A. Pirani, W. Moufouma-Okia, C. Péan, R. Pidcock, S. Connors, J. B. R. Matthews, Y. Chen, X. Zhou, M. I. Gomis, E. Lonnoy, T. Maycock, M. Tignor, T. Waterfield (eds), IPCC.

McCarthy J. J., Canziani O. F., Leary N. A., Dokken D. J., White K. S. (IPCC, 2001), Climate Change 2001: Impacts, Adaptation, Vulnerability, Cambridge University Press, Cambridge. 
Menne B., Ebi L. K. (2006), Climate Change and Adaptation Strategies for Human Health, Springer, Berlin.

Nordhaus W. D. (1994), Expert Opinion on Climate Change, “American Scientist”, JanuaryFebruary.

Nordhaus W. D. (1991a), A Sketch of the Economics of the Greenhouse Effect, "American Economic Review", Papers and Proceedings, vol. 81(2).

Nordhaus W. D. (1991b), To Slow or Not to Slow: The Economics of the Greenhouse Effect, "Economic Journal", vol. 101(407), https://doi.org/10.2307/2233864.

Qerimi Q., Sergi B. S. (2015), Development and Social Development in the Global Context, "International Journal of Business and Globalisation", vol. 14(4), https://doi. org/10.1504/ijbg.2015.069682.

Sciortino M. (2001), Desertification in the Mediterranean, Contributed Paper of the 22th ISODARCO Summer Course, Italy, Candriai, www.isodarco.it/courses/candriai01/ paper/candriai01sciortino.html (accessed: 29 October 2019).

Sergi B. S. (2003), Economic Dynamics in Transitional Economies: The Four-P Governments, the EU Enlargement, and the Bruxelles Consensus, Routledge, New York.

Sergi B. S., Popkova E. G., Borzenko K. V., Przhedetskaya N. V. (2019), Public-Private Partnerships as a Mechanism of Financing Sustainable Development (in:) M. Ziolo, B. S. Sergi (eds), Financing Sustainable Development: Key Challenges and Prospects, Palgrave Macmillan.

\section{Skutki gospodarcze zmian klimatu we Włoszech}

(Streszczenie)

Cel: Zmiany klimatu niosą ze sobą zagrożenie dla zdrowia i życia ludzi, jak również zagrożenia ekonomiczne. Celem artykułu jest omówienie wpływu konsekwencji globalnego ocieplenia na dynamikę gospodarki Włoch oraz wskazanie kosztów i korzyści, które wynikają z formułowania strategii adaptacji do zmian klimatu na konkretnym obszarze, zagrożonym szczególnie erozją brzegu morskiego i powodziami.

Metodyka badań: W artykule skupiono się głównie na analizie sytuacji tego zagrożonego obszaru, który stanowi podstawę przeprowadzonej oceny ekonomicznej.

Wyniki badań: Mimo że skutki zmian klimatu nie dotyczą tylko gospodarki, rozważenie potencjalnych strat ekonomicznych może pomóc w zrozumieniu istoty i znaczenia zagrożeń zmian klimatu. Ograniczeniem badań był brak analizy obejmującej inne zagrożone obszary przybrzeżne we Włoszech.

Wnioski: Strategie zaadaptowane w omawianych obszarach zagrożonych stanowią punkt wyjścia do formułowania nowych interesujących pytań dotyczących zagrożeń klimatycznych.

Wkład w rozwój dyscypliny: Opracowanie zawiera rozważania dotyczące globalnego ocieplenia, podkreślono szczególnie znaczenie strategii adaptacyjnej jako procesu, który zmniejsza naszą podatność na szkodliwe skutki zmian klimatu.

Słowa kluczowe: zmiany klimatu, ryzyko klimatyczne, skutki gospodarcze (ekonomiczne), strategie adaptacyjne. 